\title{
Plights and Solutions for the Reform of Province-County Direct Management in China
}

\author{
Li Kun \\ Yunnan University of Finance and Economics, P. R. China \\ (likun469974@163.com)
}

\begin{abstract}
Since 2010, China has enforcedthe reform of Province-County Direct Management (PCDM) in 8 provinces. The main contents are as following: enhancing county's social management rights, reforming financing management system, cadres system, law system and so on. The reform does good for the development of county's economy and society, but some plights and problems appear as fatigue. So we have to explore and conclude more experience from the reforming to improve the development of urban and rural, and set model and direction for county's management system.
\end{abstract}

Keywords: Province-County Direct Management; Model; Plights; Solution

\section{The Aim and Significance of the Reforming}

\subsection{Necessity for Developing County District} Economy and Market Need

China has a unitary system that power has been concentrated by central authority. Central and provincial governments have powerful rights. The situation was necessary in the early period of new China constitution, and also it was an important way for the transformation from tradition farming society to modern industrial society. This administration model has its own advantages and disadvantages. The policy has county government in an unstable and unproper rights structure, and governments' power weak, so the activity, autonomy and initiative for local economy and social service are weak. In fact, in the course of rapid urbanization, some administration rules for the phenomenon have been made. CenterProvince-county has been changed into CenterProvince-City-County. The system of City-County direct management is helpful for the municipal construction. But in the other hand, it also weakens the county government's power. Recently, with the rapid development of market economy and transformation of lower government autonomy power, the economy of county district has been improved extremely in recent 30 years. It is the engine to develop local economy and enlarge market needs.

According to the reform of administration distribution, China has more than 2800counties in the all. In all these counties, there are $70 \%$ population and $94 \%$ land of the total. So county is a very important administration power which would have bright future to develop economy and society. According to the report from Chinese Academy of Social Science, since 2008, the advanced speed for county district economy is faster than other ranks. In 2010, the GDP of county district was amount to $49.8 \%$ of the total. ${ }^{1}$ The development of county district needs government to improve their ability to afford better social services. Only on this way, can a good and influent social model be formed. Meanwhile, it is a tendency for central and provincial government to show or decrease their power toward county government. For this reason, the reform of province-county direct management is necessary to adjust county district economy and social structure. 


\subsection{Necessity for the Integration between Urban and Rural}

Because of historical factors, we made citizen identity policy, social security system, industry priority system which divided urban and rural into two-stage development level. Since 1978, the distinction between urban and rural is more and more clear and serious, and also it has done many bad effects in the society development. Stepping into 21 century, china has began to support agriculture and rural more than industry and urban. The development of small town is an important and significant way to developing rural economy, solve job-hunting for peasants and improve social relations between urban and rural. So enhancing the power and ability of county government is a key to improve quality of public social service and integration between urban and rural.

\subsection{Necessity for Enhancing County} Government's Public Social Service

At present, central government has provided the policy to improve social integration, share social outcomes equally for all ranks and construct harmonious society. As the basic unit of local district, county government plays an important role in the construction of public social service and also in rural elementary construction, social endowment insurance, medical system, duty education and so on. The average of public social service calls on government to afford more public social responsibility. The system of province-county direct management does not only improve county's finance but also develop public social service. The developments mainly focus on autonomy finance, public service and so on. PCDM lays on much emphasis on direct finance of county in order to improve fund supporting and transformation. What's more, PCDM decreases much central and provincial power to lower government, which means county government should play more important role in public social service. Only on this way, would the advantage of autonomy, activity and creativity have been taken at last.

\section{The Main Model of Provincial-County Direct} Management

2.1. A Model of Provincial-County Direct Management without Middle Municipal System

According to the Law of Constitution, china has enforced a management policy of province - county town. At present in all provinces in china, only Beijing, Shanghai, Tianjin and Chongqing have no municipal system of government management. All the above provincial-county direct management model have some common traits. The first one is low differentiations and high integration between urban and rural. The second is the provincial administration area is less, and the district's management is much easier. The third is the public social service in the district is equal relatively with high homogeneity.

\subsection{A Model of Provincial - County Direct} Management Around Finance Core System

Zhejiang, Hubei, Anhui, Jilin do well in PCDM around finance core system in China. The model is enforced in making finance policy, fund distribution, transformation, debt management and so on. Especially, Shanxi, Liaoning, Henan are good at subsidy distribution, special funds and capital dispatch in PCDM. The aim for the model is to enhance finance supporting toward county, develop county district economy and improve public social service from the connection between province and county. At present, Shandong and Guangxi have enforced the model of province toward city. Only on 
the distribution and transformation for subsidy, would the model of PCDM be enforced.

\subsection{A Model of Provincial-County Direct} Management with Cadre Management Reforming

The model of PCDM with cadre management reforming is enforced by two factors. For one thing, it is required provincial authority to have more appointment rights toward county government. For another, it is also required the municipal authority to reduce personnel appointment rights toward county. So many provinces are enforcing the model as an experimental unit. Heilongjiang has adjusted the municipal leaders to be guided by province directly. Hubei has made the rules that the main county leaders should be guided by province directly, and other vice county leaders should be guided by county directly. In Anhui province, the secretary of the Party committee of a county and the county magistrate ought to be guided by Anhui Ministry of Organization. Henan province also had the same model as above.

\subsection{A Model of Provincial-County Direct Management with Vertical Authority Management System}

Recently, the area for vertical authority management system in China is enlarging, including industry and commerce, quality testing bureau, territorial resources department, law section and so on. The advantage for the policy is obvious. For one thing, it is a useful way to concentrate power for provincial government and make responsibility clear. For another, also the disadvantage for the policy appeared. For example, with the increase of vertical authority management departments, regional government goes his own way more and more. The power of unity and entirety would be decreased. So the reform for vertical authority management should be divided into two ways. The first one is making the authority under province belong to province directly, such as Hubei and Heilongjiang. The other one is giving more power to lower authority and government. For example, some testing unit ought to be managed by county rather than province, such an Anhui province.

\section{The Plight for Provincial-County Direct Management}

3.1. Incoordination Management System between City and county

From the experience of experimental unit in PCDM, most main county leaders and authority in experimental units are listed to belong to provincial management, but other developments as the National People's Congress (NPC), the Chinese People's Political Consultative Conference (CPPC) and law bureau, indeed are guided and managed directly by county government. So there is a double management for experimental units. Some inharmonious relations appeared between province and county, which leads to have indistinct social role and responsibility. If the situation goes on, it would do enough bad effect in the development of local economy and society.

\subsection{Weak Power to Improving County Economy for City Government}

PCDM has made county's finance and tax out of management from city authority. The finance power of county belongs to province, which has city authority lost their right. So the city authority lost its finance ability to develop local economy and society. What's more, if the city authority has more finance power, it would prefer to engage the management toward the counties which are belongs to city authority management directly, because they have closer profit relations. Meanwhile, because the power 
for city authority has been decreased, the integration for city authority and county government would become more difficult.

\subsection{Difficulty in Profit Coordination for Experimental Units}

In the reforming of PCDM, most provinces select the experimental units bases on its own traits. For example, some select agriculture advanced county to be the experimental unit, others for advanced economy, advantaged location, various ethnic groups and so on. However, different counties have different advantages and disadvantages. Although the policy for the experimental unit is the same, the outcomes of them are still different. What's more, some counties fight against with other experimental units in order to get more funds and policy supports. So the profit relation becomes the key and difficulty among different experimental units.

\section{Solutions to Improve the Reforming for} Province-County Direct Management

\subsection{Enhance the Description of Upper Institutions} and Vertical Administration Construction

Since 2010, PCDM has been enforced in Anhui, Hebei, Henan, Jiangsu, Heilongjiang, Ningxia, and Yunnan provinces. The aim for the policy is to increase the experience of local administration management, make responsibility clear and improve the development of local economy and society. However, after a period of the reforming, it is largely admitted that the policy is tired, and some places just wait and see the outcome of other places. The reason for the phenomenon is divided into two parts. The first factor is how to make clear the relations among province, city and country. The reforming must be enforced according to local facts. For this reason, it is necessary for central government to design a good and practical upper administration institution.

Administration management relations of the reforming in PCDM should be advanced by three ways. The first one is make rights and responsibility clear among province, city and county. The second is developing system of cadres' management. System of cadres' management is the key for the success of PCDM. In our eyes, it is an important way to improve the system by enhancing main leaders' rights and decreasing the vice leaders' rights. The main leaders should belong to be guided by provincial government. The Vice leaders in county should belong to be guided by the local government. The third is improving system of finance management. When the finance rights are transferred partly to local county government, its power for provincial authority in funds transformation should be enhanced. Only on this way, would the local economy and society be developed at last.

\subsection{Change the Function of County Government} in Experimental Unit and Advance the Power and Level of Public social Service.

To change the function of county government is the key to have the experimental units succeeded. For the experimental units, the change of the function is the base of the innovation in institution system, policy and process. ${ }^{2}$ How to improve the change of government function? The first is making good use of the resources in market economy. For example, divide the function of government and enterprise into two parts; separate the function of government and social organization; lead government's responsibility in macro-economy, industry development and market regulation. The second is improving the power of government in public social service and making equal institution in urban and rural. For one thing, 
government should play more emphasis on elementary construction, especially in rural area. For another, government should pay more attention to develop social security system and employment system, which is helpful and useful for the development of local economy and society.

\subsection{Strength the Supervision and Control on}

\section{County Authority}

The nature for the modal of PCDM is to make all departments in county and province has clear responsibility, improve the level of government administration. For this reason, it means the reform is an activity to boast more duty and rights for county government. However, in the experimental units, it is short of the supervision and control in making institutions. The lack must play a bad role in the development of local economy and society. How to improve the phenomenon, two ways should be mentioned. for one thing, the upper authority should have more rights and chances to inspect the lower authority, including rights, special funds, audit and natural affairs. For another, government should improve the construction of supervision system, including information open system, discussion system and implement system. Only on this way, would some disadvantage of the system be restricted and decreased.

1.http://www.gov.cn./jrzg/2013-02/09/content

2330452. 9th, Feb, 2013.

2.Zhang Zhan bin, New Experiments for Provincecounty Direct Management: Listed singly in Province or Full Direct Management. Chinese Administration, $14^{\text {th }}$, March, 2013.

\section{Reference}

[1] Li DongMing, Yang Hexin. Dractice and Thoughts on the Reform of Province-County Direct Management.

[2] Zhou Bo. (2010). The key of the Reform of Province-County Direct Management. Finance Research, 3

[3] Zhang Zhan bin. (2013). New Experiments for Province-County Direct Management: Listed singly in Province or Full Direct Management. Chinese Administration, 3

[4] Pang Mingle. (2009). Rational Thoughts on Province-County Direct Management. Academic Journal for Wuhan University of Science and Technology. 